\title{
Feasibility Analysis of Shortfin Scad Fish (Decapterus spp) Business Unit in Sinjai Regency
}

\author{
Rahmatullah Arsyad', Aris Baso², Najamuddin², Hamzah Tahang², Andi Amri², Mahyuddin³, Sitti Nurani \\ Sirajuddin $^{3}$
}

${ }^{1}$ Agribusiness Study Program Students, Postgraduate School of Hasanuddin University, Indonesia

${ }^{2}$ Lecturer of Fisheries Department of Hasanuddin University, Indonesia

${ }^{3}$ Lecturer of Agribusiness Program, Postgraduate School of Hasanuddin University, Indonesia

Correspondence Author: Rahmatullah Arsyad, Agribusiness Study Program Students, Postgraduate School of Hasanuddin University, Indonesia E-mail: rahmatullaharsyad@yahoo.co.id

Received date: 28 August 2019, Accepted date: 15 November 2019, Online date: 26 November 2019

Copyright: (C) 2019 Rahmatullah Arsyad., This is an open-access article distributed under the terms of the Creative Commons Attribution License, which permits unrestricted use, distribution, and reproduction in any medium, provided the original author and source are credited.

\begin{abstract}
The fishing communities that carry out fishing activities in Sinjai Regency, in general, use purse seine which is a relatively high productivity and effectiveness tool when compared to other fishing gear. However, the effort to catch a Shortfin scad fish (Decapterus spp) has not been maximized due to the lack of catch fisheries and has not functioned optimally. The purpose of this study was to examine the feasibility of a Shortfin scad fish fishing business unit in Sinjai regency. Data collected in the form of primary data and secondary data with data collection using interview and observation techniques. The research method used is the survey method. The results showed that the feasibility analysis of the Shortfin scad fish fishing business unit in Sinjai Regency obtained an average $R$ / C Ratio of 2.42. R / C Ratio value obtained is greater than 1 , which means that this purse seine business unit is feasible to run.
\end{abstract}

Keywords: Decapterus spp, purse seine, business feasibility

\section{INTRODUCTION}

Shortfin scad fish (Decapterus spp) is a type of fish that is widely marketed in several regions of South Sulawesi, especially in Sinjai Regency. This is influenced because Shortfin scad fish is the main commodity of community consumption fish and has affordable economic value and is widely available in the market. Shortfin scad fish fishing areas are scattered in several areas such as the Makassar Strait, Flores Sea and Bone Bay. Shortfin scad fish production in Sinjai Regency in 2018 amounted to 2,900.6 tons. Catches of fishers with Shortfin scad fish commodities in Sinjai Regency are generally produced by purse seines (Purse Seine), with a higher fishing capacity than other fishing gear. But in its operation, the purse seine fishing business unit requires a large enough cost, so it requires more capital and labor [1].

Factors that influence fishermen's income are the level of profit and operational costs incurred. The more catches fishermen have, the bigger the income, to obtain high profits, operational costs must be minimized. In general, purse seine fishermen in Sinjai Regency are fishing businesses that still rely on habits such as fishing methods, fishing grounds, and fishing seasons. This has resulted in fluctuating value of capture fisheries production. Business feasibility analysis is a criterion for investing for a certain period of production. Business analysis is needed to determine the development of purse seine business in the future. To support this analysis, it is necessary to calculate economic aspects such as capital, financing, revenue, and profitability within a certain production period [2]. The purpose of this study is to calculate the economic aspects of the Shortfin scad fish fishing business unit so that it can determine the level of eligibility of the Shortfin scad fish fishing business unit in Sinjai Regency.

\section{RESEARCH METHODS}

This research was conducted in Sinjai Regency, South Sulawesi Province in August - October 2019. The data collection was carried out using a survey method for purse seine boat owners. Sampling by ship owners is done by random sampling, which is a sampling method by randomly sampling the sample, according to [3], which states that if the number of samples is less than 100, it is better to take all, but if the number of samples is more than 100 then it can be taken between 10-15\% of the population or depending on the ability of researchers, area and size of the risk borne by researchers. With the total population of purse seine in Sinjai Regency as many as 124 so if taken $10 \%$, the number of samples that can be taken is 12 samples. 
The collected data were analyzed descriptively [4]. Analysis of the fishing business using purse seine is carried out by adopting the concept of the cost structure and income of the fishing business [5]. Fishing business costs include investment costs, depreciation costs and maintenance costs, as well as variable costs or operational costs (variable costs), and other costs.

Analysis of the data used in this study is the analysis of business feasibility by looking at several aspects, namely the total cost, revenue and income which will get the business feasibility value.

A. Total Cost

To explain about the total cost in this purse seine business using the formula, [6]:

Information:

$$
\mathrm{TC}=\mathrm{TFC}+\mathrm{TVC}
$$

TC $=$ Total Cost (IDR)

TFC $=$ Total Fixed Cost (IDR)

$\mathrm{TVC}=$ Total Variable Cost (IDR)

B. Revenue

To find out the business acceptance of purse seine, use the following analysis, [6]:

Information:

$$
\mathrm{TR}=\mathrm{P} . \mathrm{Q}
$$

TR = Total Revenue

$\mathrm{P} \quad=$ Price

$\mathrm{T} \quad=$ Total of fish sold

\section{Income}

To find out the income of a purse seine business, using the following analysis [7]:

$$
\mathrm{TI}=\mathrm{TR}-\mathrm{TC}
$$

Information:

$\mathrm{TR} \quad=$ Total Revenue

TC $=$ Total Cost

D. Feasibility

All received from total receipts and total costs, which shows the value of revenue obtained from each rupiah issued. As the $\mathrm{R} / \mathrm{C}$ ratio can be formulated as follows, [7]:

Information:

$\mathrm{R} /(\mathrm{C}=\mathrm{TR} / \mathrm{TI})$

TR = Total Revenue

TI = Total Income

R / C Ratio Assessment Criteria:

$\mathrm{R} / \mathrm{C}<1=$ effort to reduce losses

$\mathrm{R} / \mathrm{C}>1=$ profit gained

$\mathrm{R} / \mathrm{C}=1=$ effort to break even

\section{RESULTS AND DISCUSSION}

Analysis of the economic aspects of the business unit purse seine can be seen by calculating the value of investment, costs, revenues and revenues. After seeing the income, it can be determined whether the feasibility of the business is feasible or not. The following is an analysis of a purse seine Shortfin scad fish fishing business unit (purse seine) in Sinjai Regency:

A. Purse Seine Fisherman Activity

Purse seine that is used by fishermen in Sinjai Regency is operated at night because it uses a lamp as a source of light. The light used is intended to attract the attention of fish. In addition to using light aids, fishermen also use FADs to increase their catch. In purse seine operations, the departure to the location of the arrest is carried out in the morning and afternoon depending on whether or not the location of the capture is far away. If the location of the arrest location is classified as far away then the departure is carried out in the morning and if the location of the arrest is classified as close then the departure is carried out in the afternoon. After arriving at the fishing location, the light boat is removed from the purse seine and then the crew members tie the rope to the FADs. When it was late at night, the lights on the main ship were lit by the crew.

At dawn, the lights were turned off in the main ship gradually one by one so that the fish that had gathered under the light was not surprised and left the area of ship, the lights on the lifeboat were turned on where the lights were placed on the right and left side of the lifeboat, then the lifeboat was brought near FADs that have previously been removed by their mooring rope from the main ship and have released the FAW main ropes, then the rope is given a buoy. After that, the ship will circle the boat of lights and FADs. The loop process takes \pm 10 minutes

\section{B. Analysis of Income the Purse Seine Business Unit}

1. Investment

Investment is investing money or capital in a business to make a profit. The total investment cost of a purse seine business unit in Sinjai Regency varies (Table 1). Based on these data, the value of each type of investment can be calculated. 
Table 1. The Average Investment Value of Purse Seine Business Unit in Sinjai Regency.

\begin{tabular}{lll}
\hline No & Types of Investment & Average Value (IDR) \\
\hline 1 & Ship & 202.083 .333 \\
2 & Nets & 100.416 .667 \\
3 & Lifeboat & 3.666 .667 \\
4 & Main ship engine & 63.333 .333 \\
5 & Additional engine & 26.666 .667 \\
6 & Roller engine & 4.075 .000 \\
7 & Generator engine & 4.400 .000 \\
8 & Basket & 3.866 .667 \\
9 & Lamp & 440.833 \\
\hline Total & & $\mathbf{4 0 8 . 9 4 9 . 1 6 7}$ \\
\hline
\end{tabular}

Source: Primary Data Analysis, 2019

Table 1 shows the overall investment value of purse seine business with an average value of IDR 408,949,167 per each business, with the highest investment value in the type of ship investment with an average value of IDR 202,083,333. That is because the type of investment in ships with expensive wood raw materials and the cost of boat building salaries are quite high.

\section{Fixed Costs}

Fixed costs are costs that are not used up in a single production process, which are included in fixed costs are depreciation costs. The amount of depreciation expense used depends on the time the investment was used (Table 2). Based on these data, the value of each investment type depreciation can be calculated.

Table 2. The Depreciation Cost Amount of Purse Seine Business Unit in Sinjai Regency.

\begin{tabular}{|c|c|c|}
\hline No & Types of Investment & $\begin{array}{l}\text { Average of Depreciation Expense } \\
\text { (IDR) }\end{array}$ \\
\hline 1 & Ship & 11.828 .704 \\
\hline 2 & Nets & 20.083 .333 \\
\hline 3 & Lifeboat & 916.667 \\
\hline 4 & Main ship engine & 4.222 .222 \\
\hline 5 & Additional engine & 2.133 .333 \\
\hline 6 & Roller engine & 271.667 \\
\hline 7 & Generator engine & 440.000 \\
\hline 8 & Baskets & 1.288 .889 \\
\hline 9 & Lamps & 315.000 \\
\hline \multicolumn{2}{|c|}{ Total } & 41.499 .815 \\
\hline
\end{tabular}

Source: Primary Data Analysis, 2019

Table 2 shows the types of fixed costs used by purse seine business units, namely, ships, nets, lifeboats, ship engines, auxiliary engines, roller engines, generator engines, basketball and lights. The average depreciation value of purse seine business units issued annually is IDR.41,499,815 with the highest depreciation value in the type of net investment of IDR 20,083,333. This is influenced by purse seine fishing gear in the form of a net that is very easily damaged or torn so that almost every month has been repaired.

3. Variable Costs

Variable Costs are costs that are used up in one production; costs are not fixed in the amount because it is influenced by the size of the amount of production obtained and the length of time the production process (Table 3 ).

Table 3. The Average Value of Variable Cost of Purse Seine Business Unit in Sinjai Regency

\begin{tabular}{llllll}
\hline No & Cigarette/Trip & Fuel/Trip & Ice Cube/Trip & Food Supply/Trip & Outcome/Year \\
\hline 1 & 280.000 & 825.000 & 75.000 & 8.000 .000 & 1.380 .960 .000 \\
2 & 285.000 & 825.000 & 75.000 & 7.000 .000 & 1.553 .760 .000 \\
3 & 280.000 & 825.000 & 75.000 & 7.000 .000 & 1.553 .280 .000 \\
4 & 280.000 & 825.000 & 75.000 & 7.000 .000 & 1.553 .280 .000 \\
5 & 285.000 & 825.000 & 75.000 & 7.000 .000 & 1.553 .760 .000 \\
6 & 180.000 & 660.000 & 75.000 & 5.000 .000 & 1.571 .760 .000
\end{tabular}




\begin{tabular}{llllll}
7 & 200.000 & 660.000 & 75.000 & 5.000 .000 & 1.574 .640 .000 \\
8 & 270.000 & 825.000 & 75.000 & 7.000 .000 & 1.552 .320 .000 \\
9 & 280.000 & 825.000 & 75.000 & 8.000 .000 & 1.380 .960 .000 \\
10 & 280.000 & 825.000 & 75.000 & 8.000 .000 & 1.380 .960 .000 \\
11 & 300.000 & 825.000 & 75.000 & 7.000 .000 & 1.555 .200 .000 \\
12 & 280.000 & 825.000 & 75.000 & 7.000 .000 & 1.553 .280 .000 \\
\hline \multicolumn{2}{l}{ Total } & & & $\mathbf{1 . 5 1 3 . 6 8 0 . 0 0 0}$ \\
\hline
\end{tabular}

Source: Primary Data Analysis, 2019

Table 3 shows the variable costs of purse seine business units in Sinjai District with an average of IDR 1,513,680,000 per year. This variable cost value is quite large because a one-time trip captures require at least 15 to 20 million operational costs and consumption costs.

\section{Total Cost}

Total costs represent all costs incurred in a business (Table 4).

Table 4. The Average Total Cost of the Purse Seine Business Unit in Sinjai Regency

\begin{tabular}{llc}
\hline No & Information & Average Total Cost (IDR) \\
\hline 1 & Fixed Cost & 39.366 .481 \\
2 & Variable Cost & 1.513 .680 .000 \\
\hline Total & & $\mathbf{1 . 5 5 3 . 0 4 6 . 4 8 1}$ \\
\hline
\end{tabular}

Source: Primary Data Analysis, 2019

All costs referred to are fixed costs and variable costs in a certain period. The average value of the total costs incurred in the purse seine business unit in Sinjai Regency is IDR 1,553,046,481 per year.

5. Revenue

Revenue is the multiplication of production obtained with the selling price (Table 5).

Table 5. The Average Revenue of Purse Seine Business Unit in Sinjai Regency

\begin{tabular}{llccc}
\hline No & Information & Revenue & Income Tax 2\% & Revenue (IDR) \\
\hline 1 & Peak Season & 1.483 .208 .333 & 29.664 .167 & 1.453 .544 .167 \\
2 & Transitional Season & 1.350 .825 .000 & 27.016 .500 & 1.323 .808 .500 \\
3 & Lonely Season & 993.075 .000 & 19.861 .500 & 973.213 .500 \\
\hline Total & & & $\mathbf{3 . 7 5 0 . 5 6 6 . 1 6 7}$
\end{tabular}

Source: Primary Data Analysis, 2019

This revenue is still the gross profit of the purse seine business which is still reduced by other costs such as income tax. The average value of purse seine fishing revenue in Sinjai Regency is IDR 3,827,108,333 per year.

6. Income

Profits represent the total net benefits derived from total revenues less the total costs incurred (Table 6).

Table 6. The Average Profit of Nilai Purse Seine Business Unit in Sinjai Regency

\begin{tabular}{lll}
\hline No & Information & Average Income (IDR) \\
\hline 1 & Total Acceptance & 3.750 .566 .167 \\
2 & Total Cost & 1.553 .046 .481 \\
\hline Total & & $\mathbf{2 . 1 9 7 . 5 1 9 . 6 8 5}$ \\
\hline
\end{tabular}

Source: Primary Data Analysis, 2019

Table 6 shows the total profit of purse seine business in Sinjai District in one year. The big profit is influenced by purse seine business units in one trip fishing can produce 2 to 10 tons of Shortfin scad fish. The average profit of a purse seine business in Sinjai Regency is IDR 2,197,519,685. 
7. Business Feasibility

The feasibility analysis of the purse seine business unit with the balanced analysis of revenues and costs is used to find out how much the costs are incurred so that it can provide many benefits from the revenues obtained (Table 7).

Table 7. Revenue Cost Ratio of Purse Seine Business Unit in Sinjai Regency

\begin{tabular}{llc}
\hline No & Information & R/C Ratio \\
\hline 1 & Total Acceptance & 3.750 .566 .167 \\
2 & Total Cost & 1.553 .046 .481 \\
\hline R/C Ratio & & $\mathbf{2 , 4 2}$ \\
\hline
\end{tabular}

Source: Primary Data Analysis, 2019

Table 7 shows the average value of the Revenue Cost Ratio in the purse seine business unit in Sinjai Regency by 2.42 . The R / C Ratio value obtained by the purse seine business unit in Sinjai Regency is greater than 1, which means that this purse seine business unit is feasible to run.

[8], in his research on the analysis of the efficiency of the use of purse seine fishing gear inputs in Pekalongan, fishing with purse seine fishing gear was quite profitable because the $\mathrm{R} / \mathrm{C}$ ratio was 1.504 . While in [9], research on the comparative technical and financial aspects of the fish cooling system for transport vessels, the R / C ratio for the cooling system in Pekalongan was 0.79 . Financially this value shows that the application of this technology needs to be reconsidered to continue. The unfeasibility of the sustainability of this system is because the amount of investment invested is not proportional to the income received from the catch. Unlike the RSW (Refrigerated Sea Water) refrigeration technology applied in Juwana, this technology is worthy of continued because the $\mathrm{R} / \mathrm{C}$ value is more than one, that is 1.27. Based on comparisons from previous studies, the value of $\mathrm{R} / \mathrm{C}$ ratio of purse seine business units in Sinjai Regency is quite profitable and feasible to be continued. This is reinforced by the value of the $\mathrm{R} / \mathrm{C}$ ratio of more than one and the acquisition of income.

\section{CONCLUSION}

Feasibility Analysis of the purse seine business unit in Sinjai district, the average R / C ratio value is 2.42 , the R / C ratio value is greater than 1, which means that each of the Shortfin scad fish fishing business units is feasible to run.

\section{REFERENCE}

[1] Hudring BS. 2012. Pukat Cincin. Jakarta (ID): Balai Besar Pengembangan Penangkapan Ikan Kementerian Kelautan dan Perikanan.

[2] Karningsih, F. Rosyid, AWibowo, B Argo, 2014. Analisis Teknis dan Finansial Usaha Perikanan Tangkap Cantrang Dan Payang Di Pelabuhan Perikanan Pantai Asem doyong kabupaten Pemalang. Journal of Fisheries Resources Utilization Management and Technology .3(3):158-167.

[3] Prasetiyo, Bambang dan Lina, M J. 2005. Metode Penelitian Kualitatif Teori dan Aplikasinya.PT. Grafindo Persada. Jakarta.

[4] Singarimbun, M. \& S. Effendi. 1989. Metodologi penelitian Survei. LP3ES. Jakarta.

[5] Panayotou, T. 1985. Cost structure and profitability of small-scale fi shing operations: A conceptual framework. In Panayotou (Ed). Small-Scale Fisheries in Asia: Sosioeconomic Analysis and Policy. International Development Research Center. Canada.

[6] Bangun, 2010. Teori Ekonomi Mikro. PT. Refika Aditama. Bandung

[7] Umar, H. 2003. Studi Kelayakan Bisnis.Jakarta

[8] Sismadi. 2006. Analisis efisiensi penggunaan input alat tangkap purse seine di kota pekalongan. Srogram $\quad$ Studi Megister Ilmu Ekonomi dan Studi Pembangunan. Program Pascasarjana. Universitas Diponegoro. Semarang. Tesis.

[9] Apriliani, T. \& A.H. Purnomo. 2005. Komparasi aspek teknis dan finansial sistem pendinginan ikan untuk kapal pengangkut. Jurnal Penelitian dan Perikanan indonesia edisi sosial ekonomi. Badan Riset Kelautan dan Perikanan. Departemen Kelautan dan Perikanan. Jakarta. 